\title{
SOCIEDADE CIVIL, ENTRE O POLÍTICO-ESTATAL E O UNIVERSO GERENCIAL ${ }^{*}$
}

\section{Marco Aurélio Nogueira}

O campo dos estudos políticos e sociais não existe sem dissonância. As categorias que se empregam para interpretar a sociedade, a organização política e os fatos culturais, por serem históricas e refletirem sempre um compromisso e uma escolha dos pesquisadores, são muitas vezes fluidas e fugazes.

* A primeira versão deste texto foi apresentada na mesa-redonda "Sociedade civil e Estado na era da globalização", integrante do "Seminário Internacional Ler Gramsci, entender a realidade”, promovido pela International Gramsci Society-IGS e pela Faculdade de Serviço Social da Universidade Federal do Rio de Janeiro em setembro de 2001. Essa versão serviu de base para um texto publicado na Revista del CLAD Reforma y Democracia, 25, 2003, que antecipa algumas das considerações feitas agora.

Artigo recebido em novembro/2002

Aprovado em abril/2003
Inúmeros conceitos da teoria social contemporânea geram controvérsias constantes. Um deles é o de hegemonia. Trata-se de um conceito empregado basicamente para caracterizar a capacidade que um grupo tem de dirigir eticamente e estabelecer um novo campo de liderança. Mas como a palavra tem origem militar, muitos a aproximam da idéia de monopólio ou uso intensivo do poder, quer dizer, vêem-na muito mais como sinônimo de força, autoridade e imposição. O conceito de consenso sofre algo parecido: elaborado para qualificar uma articulação pluralista de idéias e valores, uma unidade na diversidade, acaba por ser reduzido a ausência de dissenso e divergência, uma situação mais de silêncio passivo e unanimidade que de ruído e multiplicidade. Manuseado com esse registro, o conceito de consenso perde operacionalidade e se torna um jargão sem maior utilidade. Quando muito, vale para que se demarque uma ou outra posição em termos políticos mais imediatos. 
Ocorre algo ainda pior com o conceito de sociedade civil. Ao se disseminar largamente e colar-se ao senso comum, ao imaginário político das sociedades contemporâneas, à linguagem da mídia, o conceito perdeu precisão: empregam-no tanto a esquerda histórica quanto as novas esquerdas, tanto o centro liberal quanto a direita fascista. Os vários interlocutores referem-se a coisas distintas, mas empregam a mesma palavra. Certamente, a referência nem sempre é Gramsci, mas Gramsci está presente sempre, é sempre lembrado e muitas vezes é apresentado como parâmetro principal. Inevitável que a confusão prevaleça. Hoje, como muitos já observaram, continuamos sem uma compreensão única e consensual do termo (Whitehead, 1999; Cohen e Arato, 2000; Nogueira, 2000/ 2001; Lavalle, 1999).

A sociedade civil serve para que se faça oposição ao capitalismo e para que se delineiem estratégias de convivência com o mercado, para que se proponham programas democráticos radicais e para que se legitimem propostas de reforma gerencial no campo das políticas públicas. Busca-se apoio na idéia tanto para projetar um Estado efetivamente democrático como para se atacar todo e qualquer Estado. É em nome da sociedade civil que muitas pessoas questionam o excessivo poder governamental ou as interferências e regulamentações feitas pelo aparelho de Estado. Apela-se para a sociedade civil com o propósito de recompor as "virtudes cívicas" inerentes à tradição comunitária atormentada pelo mundo moderno, assim como é para ela que se remetem os que pregam o retorno dos bons modos e dos bons valores. É em seu nome que se combate o neoliberalismo e se busca delinear uma estratégia em favor de uma outra globalização, mas é também com base nela que se faz o elogio da atual fase histórica e se minimizam os efeitos das políticas neoliberais. Muitos governos falam de sociedade civil para legitimar programas de ajuste fiscal, tanto quanto para emprestar uma retórica modernizada para as mesmas políticas de sempre, assim como outros tantos governos progressistas buscam sintonizar suas decisões e sua retórica com as expectativas da sociedade civil. Em suma, o apelo a essa figura conceitual serve tanto para que se defenda a autonomia dos cidadãos e a recomposição do comunitarismo perdido, como para que se justifiquem programas de ajuste e desestatização, nos quais a sociedade civil é chamada para compartilhar encargos até então eminentemente estatais.

No texto que se segue, pretendo argumentar que convivemos hoje com diferentes conceitos de sociedade civil, estruturados a partir de distintos programas de ação e influências teóricas. Flutuamos entre esses conceitos, tanto no plano teórico como no mais imediatamente político. Eles, na verdade, freqüentam-se reciprocamente, remetendo-se uns aos outros. Seus impactos e desdobramentos políticos, porém, são completamente distintos, como veremos.

Para desenvolver a argumentação, este texto toma como parâmetro o conceito gramsciano de sociedade civil. Ainda que sem pretender reconstruir com detalhes a concepção de Gramsci, ${ }^{1}$ nem mapear e deslindar criticamente as diversas correntes que hoje incidem nos estudos a respeito da sociedade civil, procurar-se-á fixar o núcleo mais específico da concepção gramsciana e tomá-lo como base para dialogar com as demais idéias de sociedade civil que hoje procuram se afirmar no panorama político e cultural.

Com esse propósito, será aqui adotado o pressuposto de que, em Gramsci, sociedade civil é um conceito, complexo e sofisticado, com o qual se pode entender a realidade contemporânea. Mas é também um projeto político, abrangente e igualmente sofisticado, com o qual se pode tentar transformar a realidade. Diferentemente, porém, do que ocorre em boa parte das formulações recentes sobre a "nova sociedade civil" - que procuram fornecer um eixo de orientação para a ação política com base numa oposição axiológica entre Estado e sociedade (Lavalle, 1999) -, a teoria gramsciana encontra seu alicerce teórico e sua referência ético-política precisamente na dialética de unidade-e-distinção daquelas duas instâncias constitutivas do social. Com isso, Gramsci pôde atualizar o conceito de sociedade civil vis-à-vis as tradições oitocentistas e assimilá-lo como fundamento de sua teoria da hegemonia (Frosini, 2003). Para ele, a sociedade civil não é um mero terreno 
de iniciativas "privadas", mas tem desde logo uma "função estatal", na medida mesma em que se põe como "hegemonia política e cultural de um grupo social sobre toda a sociedade, como conteúdo ético do Estado" (Gramsci, 2000, p. 225).

\section{O conceito e sua difusão}

A história do conceito de sociedade civil remonta ao mundo clássico e medieval, a partir do qual, após longa maturação, ressurgiu colado à progressiva afirmação do pensamento liberal. Chegou ao século XIX, passando pelo Iluminismo, por Ferguson, Adam Smith e Rousseau, e infiltrou-se com destaque nas formulações de Hegel e Marx, mediante os quais se incorporou à cultura teórica contemporânea, penetrando particularmente os universos socialista e comunista. ${ }^{2}$

Ao longo do século XX, o conceito esteve fortemente associado à elaboração marxista de Antonio Gramsci, ganhando forte disseminação após a descoberta e o intenso trabalho de avaliação crítica de Cadernos do Cárcere, no pós-Segunda Guerra Mundial. A partir dos anos de 1980, os cadernos têm sido objeto de reconstituição e reinterpretação, ao qual se associam nomes como os de Norberto Bobbio, Alain Touraine, Charles Taylor, Michael Walzer e Jurgen Habermas, entre outros.

O debate sobre o tema evoluiu por uma via predominante. Ao passo que a tradição associada a Gramsci permaneceu vendo a sociedade civil como "parte orgânica" do Estado, como âmbito dotado de especificidade, mas somente compreensível se integrado a uma totalidade históricosocial, as correntes mais recentes tenderam a tratar a sociedade civil como uma instância separada do Estado e da economia, um reino à parte, potencialmente criativo e contestador, visto ora como base operacional de iniciativas e movimentos nãocomprometidos com as instituições políticas e as organizações de classe, ora como espaço articulado pelas dinâmicas da "esfera pública" e da "ação comunicativa” (Habermas, 1997a e 1997b). Transitou-se assim de uma imagem de sociedade civil como palco de lutas políticas e empenhos hege- mônicos, para uma imagem que converte a sociedade civil ou em recurso gerencial - um arranjo societal destinado a viabilizar tipos específicos de políticas públicas -, ou em fator de reconstrução ética e dialógica da vida social. De uma fase em que o marxismo preponderava nas discussões e deixava sua marca, ingressou-se numa fase em que a perspectiva liberal-democrática, nuançada ou afirmada de modo ortodoxo, prevalece e opera como referência principal.

Em termos gerais, essa recomposição e a larga difusão do conceito tiveram na base um processo objetivo, estruturado por quatro vertentes principais.

Em primeiro lugar, a complexificação, a diferenciação e a fragmentação das sociedades contemporâneas, subproduto mais expressivo do desenvolvimento capitalista das últimas décadas. Ainda que cortadas por imponentes processos de integração e estandartização, as sociedades ficaram mais diversificadas e individualizadas. Tornaram-se ambientes tensos e competitivos, onde predominam condutas fechadas em si, pouco dialógicas e muito desagregadas. Sob a base de uma diminuição do peso relativo do grande sujeito histórico da modernidade capitalista, a classe operária, que funcionava como vetor de unificação social, projetou-se um amplo conjunto de "novos sujeitos", que, em sua ação, nem sempre querem ou conseguem se unificar. A mundialização e a expansão dos mercados, que em épocas anteriores operaram como inequívoco fator de agregação e estruturação de ações coletivas, passaram a animar o livre curso de interesses sempre mais particulares e desagregados.

Em segundo lugar, o conceito foi impelido pela constituição de um mundo mais interligado e integrado economicamente, submetido tanto a redes de comunicação e informação, como a dinâmicas estruturais que relativizaram o poder dos Estados nacionais. O social ganhou maior transparência e maior autonomia relativa diante do político. As sociedades entraram mais em contato umas com as outras e passaram a assimilar influxos culturais muito mais padronizados, com que ficaram ameaçadas a autonomia e a originalidade das culturais nacionais. O mundo, porém, não se 
tornou mais igual: tornou-se, na verdade, muito diverso, com um aumento sem precedentes das distâncias que separam ricos e pobres, protegidos e desprotegidos, trabalhadores e proprietários.

A difusão do conceito também foi impulsionada, em terceiro lugar, pela crise da democracia representativa e pelas transformações socioculturais associadas à globalização, que fizeram com que a política se tornasse bem mais "espetacular", bem mais midiática e bem menos controlada pelos tradicionais operadores políticos. O protagonismo adquirido pelos meios de comunicação - pela televisão em particular - alterou em profundidade toda a esfera do político, seja modificando os termos da competição inerente a ela, seja reformulando os circuitos em que se modelam as consciências e a opinião dos cidadãos: transformou, portanto, o modo mesmo como se produz consenso, como se formam culturas e orientações de sentido, como se constroem hegemonias. Com a força adquirida pelo projeto neoliberal e o aprisionamento dos Estados nacionais (e de seus governos) na jaula da globalização, o modo predominante de produção de consenso acabou por travar a formação e o desenvolvimento de formas mais politizadas de consciência, em benefício de formas econômico-corporativas e da expansão de atitudes mentais consumistas, individualistas, medíocres, indiferentes à vida comum. Tal situação provocou impactos negativos importantes sobre o funcionamento e a identidade dos partidos políticos de esquerda, já abalados pela dificuldade de reprodução dos sujeitos sociais "clássicos" e pela diminuição do sentido das grandes utopias políticas. Em decorrência, reforçou-se o protagonismo de organizações e movimentos autônomos em relação à esfera imediatamente política e a causas de natureza "classista". Com sua firme e progressiva disseminação, esses movimentos e organizações congestionaram a sociedade civil, confundindo-se com ela. De espaço dedicado à articulação política dos interesses de classe - de terreno para a afirmação de projetos de hegemonia -, a sociedade civil se reduziu a um acampamento de movimentos. Ganhou-se em termos de organização dos interesses e mesmo de ativação democrática, mas perdeu-se em termos de unidade política.
Também contribuiu para a "redescoberta" da sociedade civil, em quarto lugar, a expansão da cultura democrática em geral e da cultura participativa em particular, com o que ganharam impulso o ativismo comunitário e, na esteira dele, os assim chamados novos movimentos sociais. Ao lado de determinações de ordem mais imediatamente econômica e política, foi com base nessa expansão que se completaram, ao longo dos anos de 1980, o esgotamento e a sucessiva crise terminal dos regimes ditatoriais na América do Sul, bem como a derrocada completa do sistema socialista do Leste europeu. Em ambos os casos - que são bem específicos e não podem ser reduzidos a meras variantes de processos de descompressão política -, o movimento pela democratização fez-se junto com uma crise do Estado e dos padrões societais então vigentes. Inúmeros movimentos, ações e organismos passaram a se enraizar num terreno que já não podia mais ser plenamente regulamentado de modo estatal, e acabaram, com isso, por impulsionar a idéia de que teria finalmente surgido uma "terceira esfera, ao largo do mercado e do Estado moderno" (Avritzer, 1994, p. 12), desvinculada de partidos, regras institucionais e compromissos formais, terra da liberdade, do ativismo e da generosidade social, a partir da qual se construiria a democracia por que se lutava. ${ }^{3} \mathrm{~A}$ expressão sociedade civil ficou, assim, colada a essa "terceira esfera", e para ela foi transferida toda a potência da ação democrática mais ou menos radical, da luta por direitos e da constituição de uma esfera pública não integrada ao estatal e assentada no livre associativismo dos cidadãos.

Em ambos os casos, a democratização combinou-se com avanços em termos de modernização capitalista e globalização, ou seja, com pauperização, diferenciação social, crise fiscal, mudanças culturais e recessão econômica, fatos que iriam comprometer precisamente a consistência, a eficácia e a qualidade da democracia, bem como das respectivas sociedades civis. Combinou-se também com enfraquecimento do Estado e da perspectiva do Estado, graças à progressiva afirmação de um "discurso satanizador do setor público" e de uma ideologia estatal "auto-incriminatória", que igualará tudo o que era estatal com a ineficiência, a corrupção e o desperdício (Borón, 1996, p. 78). A de- 
mocratização nascerá e avançará, assim, perversamente articulada com uma desvalorização do político e uma recusa à política institucionalizada, ou seja, com uma despolitização da política e da cidadania. Num primeiro momento, portanto, durante os anos de autoritarismo, a sociedade civil apareceu como cenário opaco, pouco denso e cortado por interesses particulares exacerbados, divergentes, mal compostos e certamente necessitados de politização, fato que por si só justificaria a observação de Arato de que "é questionável que uma coisa inexistente (a sociedade civil num regime totalitário) possa, apesar disso, contribuir para sua própria libertação" (1995, p. 19). Num segundo momento, com o avanço neoliberal da democratização, a sociedade civil fragmentou-se toda, assistiu ao empobrecimento de muitos de seus setores e ficou ainda mais vazia de dimensão éticopolítica, com sintomas de um "regresso hobbesiano" que a incapacitaria para se repor "civilizadamente". Apesar disso, continuou a crescer o elogio unilateral de uma sociedade civil que conteria as melhores virtudes sociais e poderia se contrapor ao momento autoritário, repressivo e burocrático do fenômeno estatal. Ao reconhecido excesso de Estado típico do período ditatorial e ao mau funcionamento do Estado democrático, iria se confrontar uma postura tendencialmente hostil a qualquer Estado (Nogueira, 1998b).

Ao longo desse amplo movimento históricosocial, novas idéias de sociedade civil foram sendo elaboradas e incorporadas ao léxico contemporâneo. Como representação da prevalência do mercado, ou seja, numa linha doutrinária que se confundiria com o liberalismo econômico, com o liberismo, cresceu uma imagem da sociedade civil como expressão ou de uma solidariedade comunitária, ou de uma espécie de "revanche" do econômico sobre o político, como locus de realização das potencialidades do indivíduo, do bourgeois sobre o citoyen, para lembrar uma famosa expressão utilizada por Marx. Com tal inflexão, despolitizava-se a sociedade civil, que passava então a ser pensada ou como trincheira para proteger o indivíduo e as associações voluntárias contra o Estado, ou como ambiente capaz de recompor as tradições cívicas destruídas pelo mercado. A imagem ficaria bem ilustrada com a definição de Dahrendorf: "A sociedade civil é a essência vital da liberdade; seu caos criativo de associações dá às pessoas a possibilidade de viver suas vidas sem ter que mendigar do Estado ou de outros poderes" (1997, p. 84).

Por outro lado, como representação do crescimento da democracia participativa e da assimilação pelas esquerdas do núcleo mais "heróico" do liberalismo democrático, cresceu uma imagem de sociedade civil como esfera plural de interesses que, mediante progressivas ações associativas meritórias, daria curso a uma "vontade geral" quase redentora, a um "programa que busque representar os valores e interesses da autonomia social perante o Estado moderno e a economia capitalista, sem cair em um novo tradicionalismo" (Cohen e Arato, 2000, p. 54). Para isso, a imagem criada pela esquerda liberal-democrática também foi levada a destruir o vínculo orgânico entre a sociedade e o Estado (peça-chave da operação teórica que chega até Gramsci) e a hierarquizar axiologicamente essas duas instâncias, de modo a "negativizar" o Estado e "positivizar" a sociedade civil. Fixou-se assim um conceito de sociedade civil visto como "momento oposto ao Estado, sem qualquer liame ou intercâmbio conformativo que não seja dado a posteriori, isto é, apenas como decorrência de seu confronto" (Lavalle, 1999, p. 131).

De um modo ou de outro, portanto, a "redescoberta" do conceito de sociedade civil implicou uma revisão radical da formulação gramsciana. Para tornar ainda mais complexo e confuso o quadro, parte dessa revisão irá se fazer declaradamente a partir de uma incorporação ativa do léxico de Gramsci e muitas vezes em seu nome.

\section{A sociedade civil político-estatal}

O conceito de sociedade civil foi concebido por Gramsci - que o resgatou da tradição iluminista e hegeliana dos séculos XVIII e XIX e o renovou com radicalidade - como parte de uma operação teórica e política dedicada a interpretar as imponentes transformações que se consolidavam nas sociedades do capitalismo desenvolvido (altera- 
ções no padrão produtivo, expansão da classe operária, crescimento do associativismo, da diversificação e da organização dos interesses, socialização da política, maior peso do Estado vis-à-vis o mercado, aumento da regulação e das políticas de proteção e bem-estar etc.) (Nogueira, 1998a). Gramsci percebia que esse movimento era virtualmente unificador e continha um impulso claro em direção a formas mais avançadas de convivência, mas estava cortado por fortes tendências desagregadoras, competitivas, individualistas. O próprio Estado estava sendo reconfigurado: era invadido pela socialização da política que se verificava e levado a ir além do aparato repressivo e coercitivo. A força requeria sempre mais consenso e hegemonia. O Estado se "ampliava" (Buci-Glucksmann, 1980), articulando-se com a "nova" esfera do ser social que se objetivava em conjunto com uma maior diferenciação social e uma melhor organização dos interesses. A idéia gramsciana de sociedade civil espelharia a nova situação: abrigava a plena expansão das individualidades e diferenciações, mas acomodava também, acima de tudo, os fatores capazes de promover agregações e unificações superiores. Ela seria a sede de múltiplos organismos "privados", mas nem por isto menos estatais. Seus integrantes estariam dispostos como vetores de relações de força, como agentes de consenso e hegemonia, candidatos a "se tornar Estado".

Com o Estado reforçado conectando-se com múltiplas associações particulares e incorporando-as a si, todo o espaço estatal ganhava nova qualidade e o fato mesmo da dominação política era redefinido: a coerção - "monopólio legítimo da violência" (Weber), ação típica do Estado visto como "sociedade política" - tinha de ser cada vez mais sintonizada com a busca de consensos. Nos Cadernos do Cárcere, Gramsci esclareceu que o ato de governar continuaria a buscar o "consenso dos governados", mas não apenas como "consenso genérico e vago" que "se afirma no instante das eleições", e sim como "consenso organizado". O Estado, observava, "tem e pede o consenso, mas também 'educa' esse consenso através das associações políticas e sindicais, que, porém, são organismos privados, deixados à iniciativa privada da classe dirigente" (Gramsci, 2000, p. 119). O terreno das associações privadas tornava-se, assim, uma espécie de "dimensão civil" do Estado, base material da hegemonia política e cultural. Estado (coerção) e sociedade civil (consenso) passavam, desse modo, a ser vistos como instâncias distintas mas integradas, formando uma unidade. Reuniam-se, portanto, dialeticamente. O Estado, dizia Gramsci, é sempre uma combinação de hegemonia e coerção. "O exercício 'normal' da hegemonia, no terreno tornado clássico do regime parlamentar - escreverá -, caracteriza-se pela combinação da força e do consenso, que se equilibram de modo variado sem que a força suplante muito o consenso, mas, ao contrário, tentando fazer com que a força pareça apoiada no consenso da maioria, expresso pelos chamados órgãos da opinião pública" (Idem, p. 95).

A sociedade civil gramsciana condensa, nesse sentido, o campo mesmo dos esforços societais dedicados a organizar politicamente os interesses de classe - constantemente fracionados pela própria dinâmica do capitalismo -, cimentá-los entre si e projetá-los em termos de ação hegemônica. O associativismo é a base de tudo, mas desde que tratado politicamente. Gramsci não via grande vantagem na agregação pela agregação, na agregação em função de interesses restritos: sua ênfase repousava na superação política dessa disposição espontânea dos indivíduos e grupos sociais (Gramsci, 1987). Dava-se o mesmo com a consciência econômico-corporativa: ela existia como estado primário da consciência social, e devia ser superada pela forma mais sofisticada da consciência política, promovendo-se assim, como se diz nos Cadernos, "a passagem nítida da estrutura para a esfera das superestruturas complexas" e o ingresso numa fase em que as ideologias lutam entre si até que "uma delas, ou pelo menos uma única combinação delas, tenda a prevalecer, a se impor, determinando, além da unicidade dos fins econômicos e políticos, também a unidade intelectual e moral" (Gramsci, 2000, p. 41). A própria noção de hegemonia - par lógico e político do conceito de sociedade civil - desdobrava-se num empreendimento unificador. No entendimento de Gramsci, o sujeito hegemônico seria aquele que viesse a se mostrar mais vocacionado para agregar 
e unificar do que para separar e diferenciar. Seria nessa condição, aliás, que ele poderia se afirmar como "dirigente intelectual e moral" ou como fundador de Estados.

Isso significa dizer que a política - entendida como fator de mediação, um campo onde se combinam atos, regras e instituições voltadas para a conquista do poder, da direção e da liderança, bem como para a organização dos interesses e da própria vida comum, ou seja, entendida como campo do Estado em sentido amplo - é o principal motor de agregação e unificação das sociedades. Evidentemente, trata-se aqui tanto da política dos políticos, isto é, a política praticada pelos profissionais da política, como da política dos cidadãos (Nogueira, 2001, cap. 5) inerente ao modo de ser do homem, ou seja, tanto da política institucionalizada, como da socialmente experimentada. Para dizer de outro modo, Gramsci imaginava a política como "ética do coletivo" (Buey, 2001), já que se destinava a viabilizar uma integração da virtude privada e da virtude pública, dos interesses particulares e da vontade geral, do Estado e da sociedade, em suma, a possibilitar uma dissolução das distinções entre governantes e governados, "simples" e intelectuais (Tortorella, 1998). A política, para ele, vista como mundo político e como atividade política, representava o "meio" que viabilizava a "catarse", ou seja, "a passagem do momento meramente econômico (ou egoístico-passional) ao momento éticopolítico, isto é, a elaboração superior da estrutura em superestrutura na consciência dos homens" (Gramsci, 1999, p. 314).

Vê-se, portanto, que a sociedade civil gramsciana não se sustenta fora do campo do Estado e muito menos em oposição dicotômica ao Estado. Ela é uma figura do Estado, e foi enfatizada por Gramsci como a grande novidade que, na passagem do século XIX para o século XX, modificava a natureza mesma do fenômeno estatal, encaminhando-a em direção à idéia do "Estado ampliado". Ela se articula dialeticamente no Estado e com o Estado, seja esse entendido como expressão jurídica de uma comunidade politicamente organizada, como condensação política das lutas de classes ou como aparato de governo e intervenção. Não se mostra acertado, portanto, o pressuposto de Cohen segundo o qual "Gramsci foi o primeiro e o mais importante marxista a refutar a redução economicista do conceito de sociedade civil e a insistir em sua autonomia e em seu destaque do Estado, ou seja, da sociedade política" (Cohen, 1999, p. 268).

Gramsci pensava numa sociedade civil que se poderia chamar de político-estatal, de modo a acentuar que, nela, a política comanda: luta social e luta institucional caminham juntas, articulandose a partir de uma estratégia de poder e hegemonia. A famosa fórmula gramsciana é, aqui, eloqüente: SP + SC = Estado, quer dizer, "na noção geral de Estado entram elementos que devem ser remetidos à noção de sociedade civil (no sentido, seria possível dizer, de que Estado $=$ sociedade política + sociedade civil, isto é, hegemonia couraçada de coerção)" (Gramsci, 2000, p. 244).

Entendida por ele como "conteúdo ético do Estado", a sociedade civil possibilita a articulação e a unificação dos interesses, a politização das ações e consciências, a superação de tendências corporativas ou concorrenciais, a organização de consensos e hegemonias. Seus personagens típicos são atores do campo estatal em sentido amplo. Em decorrência, o Estado que corresponde a essa sociedade civil é um Estado que poderíamos chamar de máximo: um Estado social radicalizado, democrático e participativo, que se põe como dínamo da vida coletiva e parâmetro geral dos diversos interesses sociais, balizando-os, de algum modo compondo-os e, sobretudo, liberando-os para uma afirmação plena e não-predatória.

Nessa concepção, portanto, a sociedade civil é considerada um espaço onde são elaborados e viabilizados projetos globais de sociedade, se articulam capacidades de direção ético-política, se disputa o poder e a dominação. Um espaço de invenção e organização de novos Estados e novas pessoas. Um espaço de luta, governo e contestação, no qual se formam vontades coletivas.

Para falar em termos de uma metáfora visual, a sociedade civil político-estatal sugere uma formação em linhas convergentes: fogo concentrado no coração do sistema, maior capacidade de processar e articular demandas, maiores oportunidades de interferir na vida coletiva como um todo, eleger ou combater governos. Dada a maior predisposição 
ético-política de seus protagonistas principais (partidos políticos e assemelhados), criam-se nela condições para o aparecimento de diversos pontos "ótimos" de unificação, o que potencializa e requalifica a movimentação social.

Em sua configuração típico-ideal, essa sociedade civil produz incentivos basicamente organizacionais e integradores: unificação, politização e fortalecimento do interesse público e democrático. Desse ponto de vista, a sociedade civil político-estatal é o campo por excelência do governo socialmente vinculado e da contestação política. Nela podem se articular movimentos que apontam seja para a construção de hegemonias, seja para o controle e o direcionamento dos governos, seja para a regulação estatal e o delineamento de soluções positivas para os problemas sociais.

\section{O universo gerencial e o ativismo global}

O conceito gramsciano de sociedade civil, porém, não é hoje hegemônico: não é capaz de dirigir. Justamente porque a globalização traz consigo impulsos irrefreáveis de fragmentação, diferenciação e individualização, de "desnacionalização” e fronteiras estatais porosas, de desconexão entre pessoas, grupos e Estados, de enfraquecimento da solidariedade social (Habermas, 2001), de "destruição do passado" (Hobsbawm, 1995, p. 13), o político-estatal deixou de poder funcionar como pólo magnético. Tudo parece "emprestar certo charme à dissolução crescente da modernidade organizada" e anunciar, como programa pósmoderno, o "fim da política" (Habermas, 2001, pp. 111-112).

Em decorrência, as categorias referenciadas pelo Estado e pelo político tendem a perder valor e a ser objeto de múltiplas tentativas de ressignificação. As idéias alternativas de sociedade civil exprimem bem isso. Tendo como eixo um esforço comum para pensar o Estado, a sociedade e a economia como âmbitos autônomos, ainda que relacionados, afirmaram-se nas últimas décadas, em diálogo com Gramsci e com ele concorrendo, duas vertentes teóricas distintas, mas não contrapostas.
A primeira e a mais importante dessas idéias sobretudo pela capacidade de influência que tem tido - pode ser chamada de sociedade civil liberista. Nela, o mercado comanda: a luta social fazse em termos competitivos e privados, sem maiores interferências públicas ou estatais. Sua expressão poderia estar numa fórmula oposta à de Gramsci: $S C+$ Mercado $\neq$ Estado, ou seja, o Estado mostra-se como o outro lado tanto do mercado e da sociedade civil, como de eventuais alianças ou combinações entre eles. Numa variante atenuada, de tipo liberal-social, essa sociedade civil vê-se como um "setor público não-estatal", palco de organizações que são "públicas" porque estão voltadas para o interesse geral, mas que são "não-estatais" porque estão soltas do aparelho de Estado (Bresser-Pereira e Cunilll Grau, 1999).

Nessa idéia de sociedade civil não há lugar para a questão da hegemonia. Nela, não se trata de saber se algum ator pode ou não prevalecer e dirigir a sociedade, mas de verificar como os atores atuam para obter vantagens ou extrair maiores dividendos para si, ou seja, maximizar seus próprios interesses. Trata-se de um espaço cujos personagens típicos são atores que se organizam ou de modo restrito, egoístico, ou de modo desinstitucionalizado (por exemplo, no plano do voluntariado ou do assistencialismo tradicional). Não há ações que pretendam a conquista do Estado, mas ações contra o Estado ou indiferentes em relação a ele. Em decorrência, o Estado que corresponde a essa sociedade civil é um Estado mínimo, reduzido às funções de guarda da lei e da segurança, mais liberal e representativo do que democrático e participativo.

Nessa concepção, a sociedade civil é externa ao Estado - uma instância pré-estatal ou infra-estatal -, e nela se busca compensar a lógica das burocracias públicas e do mercado com a lógica do associativismo sociocultural. Um espaço a partir do qual se pode ferir e hostilizar os governos, mas de onde não se estruturam governos alternativos ou movimentos de recomposição social. Nele, pode existir oposição, mas não contestação.

Essa idéia também encontra um desdobramento de ordem mais "prática". É que a linguagem do planejamento e da gestão incorporou a 
tese da participação, redefinindo-a em termos de cooperação com os governos, gerenciamento de crises e implementação de políticas. A sociedade civil - locus privilegiado da participação - ingressou assim no universo gerencial, um espaço evidentemente "neutro", ocupado por associações não-governamentais despojadas de maiores intenções ético-políticas, sede de intervenções sociais "privadas" e sem fins lucrativos dedicadas a ativar determinadas causas cívicas ou a auxiliar os governos no combate à questão social (Torres, 2003). Com isso, o conceito de sociedade civil reiterou a ruptura do vínculo orgânico entre sociedade e Estado, mas também atenuou o fervor ético inerente a formulações mais progressistas. Como estabeleceu Bresser-Pereira, "a sociedade civil é a parte da sociedade que está fora do aparelho de Estado. Situada entre a sociedade e o Estado, é o aspecto político da sociedade: a forma por meio da qual a sociedade se estrutura politicamente para influenciar a ação do Estado" (1999, pp. 69 e 72). Apesar disso, "não podemos cometer o equívoco de atribuir a ela um papel libertador, tornando-a a consubstanciação do interesse público".

Esse conceito de sociedade civil estará na base teórica do chamado "Terceiro Setor", entendido como um vasto conjunto de organizações sociais voltadas para o atendimento de necessidades e carências de certos segmentos da população e unidas por uma mesma legislação reguladora (Coelho, 2000; Bresser-Pereira e Cunill-Grau, 1999). Ao passo que o movimento progressista tenderá a ver o "Terceiro Setor" como arena de ações cívicas alternativas e/ou de operações antisistêmicas mais ou menos radicais (Fernandes, 1994; Ioshpe, 1997; Vieira, 2001), a cultura neoliberal não se cansará de saudá-lo como instância capacitada para "substituir" o Estado, trocando as ações públicas permanentes e gerais por iniciativas tópicas ou locais não necessariamente coordenadas, tendo em vista uma gradual eliminação da responsabilidade estatal para com a questão social (Montaño, 2002; Behring, 2003). ${ }^{4}$

Recorrendo-se a uma imagem, pode-se dizer que a "sociedade civil liberista" sugere uma formação em linhas paralelas: as energias sociais correm lado a lado, mas não se alimentam reci- procamente. Ferem os governos em um número maior de pontos, mas não chegam propriamente a encurralá-los. São muitas vezes por eles manipuladas. A dispersão dos movimentos ajuda a que eles apenas margeiem e irritem o Estado. A dinâmica geral não é anti-sistêmica.

Em sua configuração típico-ideal, essa sociedade civil produz incentivos basicamente competitivos: re-fragmentação, fechamento corporativo dos interesses, despolitização. Nela tendem a se articular movimentos direcionados para valorizar interesses particulares, atender demandas, fiscalizar governos, desconstruir e desresponsabilizar o Estado, enfraquecer ou desativar dispositivos de regulação.

A segunda idéia alternativa de sociedade civil costuma ser vista e concebida como uma extensão crítica do conceito de Gramsci, mas nem sempre se distingue da sociedade civil liberista. Pode ser denominada de sociedade civil social.

Nela, a política está presente e tem lugar de destaque, mas nem sempre comanda: a luta social muitas vezes exclui a luta institucional e com ela se choca, impossibilitando ou dificultando o delineamento e a viabilização de estratégias de poder e hegemonia. Sua expressão poderia estar na fórmula $S C-S P \neq$ Estado $? \neq$ Mercado, quer dizer, a sociedade civil surge como uma esfera isolada dos demais âmbitos. Recusa-se a se deixar "diluir" no institucional (entendido sobretudo como sistema político e partidário), já que se concebe como maior do que ele e imune a seus desvios e degradações. Seu lema poderia ser tomado de empréstimo do velho slogan "de costas para o Estado, longe do Parlamento", usado como título de um conhecido artigo de Tilman Evers (1983).

Nessa sociedade civil há lugar para a questão da hegemonia, mas ele está imperfeitamente definido. É que os interesses, aqui, se mostram refratários a articulações superiores ou à quebra de atitudes corporativas: sua maior virtude é a autonomia. Seus personagens típicos são atores que operam na fronteira do Estado: os novos movimentos sociais, fortemente concentrados na vocalização de metas não "materiais", tópicas e particulares, muitas vezes concebidas como "políticas de identidade" (étnicas, religiosas, culturais, de gê- 
nero). Age-se, aqui, para usar o Estado tendo em vista a reforma do social. A orientação supra-institucional soma-se a uma orientação tendencialmente supranacional. Operando em rede e por intermédio do que se está convencionando chamar de cibermilitância, os movimentos sociais estariam buscando ativar a constituição de uma sociedade civil mundial (Moraes, 2001; Gómez, 2000; Walzer, 1998; Habermas, 2001; Wood, 2001). Em conseqüencia, o Estado que corresponde a essa sociedade civil é um Estado que poderíamos chamar de cosmopolita: territorialmente desenraizado e categoricamente voltado para a proteção dos direitos de cidadania - concebidos para serem viáveis num terreno supranacional -, mas também capacitado para impor limites e restrições ao mercado.

Tal modalidade de sociedade civil estaria composta por movimentos que se auto-organizam e se autolimitam e que poderiam, acredita-se, disciplinar as instituições mais sistêmicas, como o Estado e o mercado. Estruturando-se como um sistema independente e que se auto-referencia, a sociedade civil poderia moderar os excessos do Estado e do mercado e estabelecer-se como um campo onde a composição social se recriaria. Impregnada da função de intermediar o sistema político e os grupos sociais, a sociedade civil criaria condições para que se formasse uma "vontade pública" dotada da capacidade de se institucionalizar nos corpos parlamentares e nos tribunais, para falar num tom não muito distante do léxico de Habermas. Não é por outro motivo que essa idéia de sociedade civil se abre bastante para os temas da comunicação intersubjetiva, dos vínculos culturais espontâneos, da "desobediência civil" e do ativismo ético.

No fundo, a sociedade civil social exclui os interesses e as classes, supondo-se como uma espécie de universal abstrato, acessível apenas aos bons valores, aos atores "eticamente superiores", aos representantes da "vontade geral". Os interesses, em sua materialidade bruta e suja, estariam fora dela: no político, nos governos, no Estado. Por esse caminho, a sociedade civil social despoja-se do político e separa-se do Estado. Há política nela, com certeza, mas se trata de uma política convertida em ética, que não se apresenta como poder, dominação, hegemonia e Estado e, portanto, com poucas chances de se efetivar.

Por mais generosa que seja essa visão, ela se mostra pouco factível e seguramente imperfeita em termos lógicos e políticos. Não é por outro motivo que Habermas, por exemplo, prefira falar em "democracia pós-nacional" e não em "democracia cosmopolita”, para sugerir que a primeira não só mantém ativos os sistemas político-estatais nacionais, como também preserva as comunidades políticas nacionais requeridas pelo exercício democrático, ao passo que a "democracia cosmopolita" conceberia uma comunidade inclusiva carente da "autocompreensão ético-política dos cidadãos", ou seja, da possibilidade efetiva de uma "autodeterminação coletiva" (Habermas, 2001, p. 136). Ainda que os cosmopolitas consigam uma organização global que traga consigo uma representação democraticamente eleita - coisa, de resto, de difícil imaginação -, "eles não podem criar a consciência normativa a partir de uma autocompreensão ético-política, ou seja, diferenciada de outras tradições e orientações valorativas, mas antes apenas a partir de uma autocompreensão jurídico-moral". O cosmopolitismo não tem como aceitar a hipótese política da "exclusão", quer dizer, do estabelecimento de distinções entre membros e não-membros. Em decorrência, na comunidade cosmopolita, "a moldura normativa constitui-se apenas de 'direitos humanos', ou seja, de normas jurídicas com conteúdo exclusivamente moral" (Idem, p. 136).5

A sociedade civil social sustenta-se, assim, sobre uma concepção dicotômica: nela estariam o universalismo, a ética, o diálogo, ao passo que no político estariam o particularismo, a força, a corrupção. Sua teoria trabalha com um construto formal - um modelo - carregado de preferências valorativas, a partir dos quais se julga a integridade moral e a estatura política dos atores. Nessa concepção, portanto, a sociedade civil é um espaço situado além da sociedade política, do Estado e do mercado. Um espaço de onde se busca extrair, dos governos, elementos para restringir o mercado e liberar energias societais autônomas. Nele, age-se para contestar o poder e o sistema, mas não para articular capacidades de direção éticopolítica ou fundar novos Estados. 
Essa idéia também sugere uma formação em linhas paralelas, expressão de uma certa anarquia ou da ausência de maior coordenação: as ações se fazem quase sempre em rede, sem prever regularidades ou hierarquias organizacionais. Mas o alvo aqui é o sistema, mais do que os governos propriamente ditos, que não chegam a ser muito molestados. Tratar-se-ia bem mais de dar curso à configuração de uma sociedade civil mundial do que de lutar por governos alternativos. A dispersão dos movimentos faz com que a aberta contestação do sistema não chegue a se completar ou a receber um tratamento politicamente mais produtivo. De qualquer modo, ao menos em boa parte das ações, a expectativa é que a ativação da sociedade civil mundial promova uma espécie de encapsulamento dos diversos governos, forçando-os a uma atuação socialmente mais responsável.

Em sua configuração típico-ideal, essa sociedade civil produz incentivos basicamente libertários e mobilizadores: movimentação permanente, autonomia, aquisição de direitos. Desse ponto de vista, é um campo de contestação ao sistema, mas não de governo do sistema. Nela podem se articular ações direcionadas para criar éticas alternativas, organizar redes e fóruns de resistência, ativar a cidadania mundial, pressionar e encurralar governos, postular novos modelos de políticas públicas, maior justiça social ou melhor distribuição de renda (entre grupos e entre nações).

Tanto a sociedade civil social como a liberista sustentam-se sobre uma valorização da sociedade civil em si, isto é, como esfera própria, autônoma diante do Estado e a ele tendencialmente oposta, uma instância homogênea e integrada por intenções comuns, que se comporiam "espontaneamente". Com isso, dá-se passagem a uma idéia de sociedade civil vazia de tensões, disputas ou contradições, uma sociedade civil que "luta" mas que não está atravessada por lutas e que, por isso, não se estrutura como um campo de ações dedicadas a organizar hegemonias.

Evoluindo nesse sentido, a sociedade civil passou a ser configurada como uma arena onde os interesses poderiam se manifestar livremente, onde se descobririam novas virtudes gerenciais, onde se afirmaria a autonomia social e onde os atores, por meio de interações dialógicas, comunicativas, como diria Habermas, criariam as conexões essenciais da convivência democrática. Um arranjo, portanto, propenso bem mais ao prolongamento da fragmentação e do não-estatal do que ao encontro de novas bases de unificação e unidade política, onde haveria, em suma, pouca procura de consenso (hegemonia), pouca organização e pouca "força”, e, em contrapartida, muito agir comunicativo, muita disposição para o diálogo e a solidariedade. De acordo com Montaño, seja como "agir comunicativo no mundo da vida" e como "livre associativismo", seja como "interação" e como "ações voluntárias", os novos conceitos de sociedade civil isolam essa esfera da tensa e contraditória totalidade social:

\{...] pensam a mudança social, a democratização da sociedade, o aumento de poder e controle do cidadão, como resultado da atividade cotidiana da sociedade civil (como unidade), contra o Estado, em parceria com este ou com independência deste. Nenhum resultado, a não ser a constante reprodução da ordem e do status quo, sairá desta perspectiva (Montaño, 2002, p. 266).

A sociedade civil, porém, não é a extensão mecânica da cidadania política ou da vida democrática. Longe de ser um âmbito universal, é um território de interesses que se contrapõem e só podem se compor mediante ações políticas deliberadas. Não é uma área social organizada exclusivamente pelos bons valores ou pelos interesses mais justos, mas um terreno que também abriga interesses escusos, idéias perversas e valores egoísticos, no qual podem se desenvolver muitas atitudes e condutas "incivis" (Whitehead, 1999), o que levou alguns estudiosos a visualizarem uma "sociedade incivil" como caso extremo de uma sociedade civil tomada pela incivilidade (Keane, 2001, p. 115).

Ao cortarem, portanto, os vínculos da sociedade civil com o Estado e conceberem essas duas esferas como duais e não-integradas, as novas teorizações sobre a sociedade civil deixam de reconhecer que os riscos que ameaçam esse espaço social não derivam do estatismo invasivo, mas da 
"incivilidade" e do "canibalismo social" inerentes a uma sociedade "liberada do Estado" (Whitehead, 1999), isto é, não estruturada por um Estado que contrabalance as desigualdades e faça com que valores gerais (justamente os da cidadania política) prevaleçam sobre interesses particulares-egoísticos. Do mesmo modo, se se enfatiza unilateral e axiologicamente o associativismo - considerandoo um âmbito de autenticidade social e virtude cívica, por exemplo -, pode-se não só esvaziar o político-estatal de sentido, como também oferecer justificativas para as posições que, em nome da recuperação das "tradições perdidas", da pureza popular ou do espontaneísmo social, combatem justamente as funções reguladoras e distributivas do Estado, valendo-se muitas vezes de expedientes autoritários ou paternalistas.

Pode-se, por exemplo, na esteira de um certo comunitarismo neoconservador, concluir que o declínio cívico e moral da sociedade (a violência, a pornografia, o egoísmo, a droga, o consumismo) deve-se ao excesso de desenvolvimento, de política institucional (de "politicagem") ou de direitos regulamentados. Como solução, seria possível acenar-se tanto com a redução do político-estatal como com a "re-tradicionalização" da sociedade, um fechamento em si mesma, à margem do Estado, dos direitos básicos do indivíduo, em benefício da família, da comunidade e do "capital social" como um todo (Cohen, 1999, p. 275).

\section{Desdobramentos possíveis}

Todas essas concepções de sociedade civil cabem na realidade contemporânea. Na verdade, elas espelham essa realidade e tentam ao mesmo tempo direcioná-la: trazem consigo projetos políticos e sociais correspondentes. Em boa medida, oscilamos entre elas, sentindo seus efeitos e reflexos.

Muitos dos movimentos ou ações que se vinculam ao chamado "Terceiro Setor" - hoje bem numerosos, diversificados e ideologicamente plurais - transitam com bastante desenvoltura por essas modalidades de sociedade civil. Sem querer simplificar demais um quadro que é seguramente complexo, creio ser possível sustentar que quan- to mais uma iniciativa social se deixa contagiar por uma perspectiva ético-política superior, mais ela tende a flutuar entre a sociedade civil políticoestatal e a sociedade civil social. Por outro lado, quanto mais uma ação se explicita, por exemplo, como voluntariado ou assistencialismo tradicionais, mais ela tende a se firmar no terreno da sociedade civil liberista.

O fato mesmo de essas modalidades encontrarem ressonância no mundo contemporâneo faz com que elas, muitas vezes, sobretudo quando traduzidas em ação prática, se confundam e se interpenetrem umas nas outras. Uma iniciativa de promoção socioeducacional financiada por uma grande empresa capitalista, tendo em vista exclusivamente a melhoria de certas condições de vida ou o atendimento de certas demandas, não deixaria de produzir efeitos de uma sociedade civil político-estatal, ainda que, em boa medida, deva ser vista como típica da sociedade civil liberista. Dar-se-ia o mesmo com os movimentos que se vinculam claramente à sociedade civil social, alguns dos quais trafegam na fronteira com a sociedade civil político-estatal e com ela dialogam abertamente.

Tudo somado, a distinguir as ações entre si estaria o modo diverso de pensar o Estado e de conceber a relação com o governar, assim como o modo de tratar o problema das tensões entre luta social e luta institucional.

Diante desse quadro, repõe-se a questão de saber como lidar com a fragmentação que parece ter-se instalado no coração das sociedades contemporâneas, como unificar os interesses sem diminuir a diferenciação e as grandes margens de liberdade e individualidade adquiridas ao longo do tempo, como, em suma, unificar e organizar sem burocratizar, tolher e homogeneizar. A discussão sobre sociedade civil pode ajudar a que se encontrem respostas para essa questão. Nela, no fundo, oculta-se um problema maior: o da hegemonia, o de saber com que valores, projetos e ideais caminharemos ao longo do século XXI.

O conceito gramsciano de sociedade civil por sua natureza eminentemente política e estatal, quer dizer, por sua capacidade de refletir aquele espaço que, na realidade das sociedades complexas, possibilita uma oportunidade de unificação e 
agregação superior - mostra sua utilidade justamente por criar uma espécie de zona-limite da desagregação social.

A sociedade civil social - que, hoje, prepondera nos ambientes democráticos e de esquerda - expressa uma indignação em marcha. Trata-se, antes de tudo, de um campo de resistência. Sua fragmentação é em boa medida inevitável, já que espelha uma situação explosiva, multifacetada, complexa, despojada de centros organizacionais. Não há nela, ainda, por isso, sujeitos capazes de se universalizarem, ou seja, de fixarem projetos em condições de converter a resistência em "ataque", em estratégia de poder, em anúncio de um futuro desejável para todos. Enquanto projeto político, ela se mostra essencialmente como uma tradução daquilo que já foi chamado de "sociedade civil de baixo", seja no sentido de identificar os atores do campo econômico por oposição ao Estado, seja para reduzir a sociedade civil a tudo o que é considerado "bom e louvável" (Houtart, 2001, p. 93). A unificação dessa sociedade civil torna-se, assim, problemática; em certa medida, seu próprio modo de ser a inviabiliza. Ao mesmo tempo, porém, o constante e dedicado ativismo de seus integrantes pode facilitar e impulsionar a disseminação de éticas alternativas que, pelos interstícios do sistema global, contribuem para o desgaste político ou mesmo a condenação moral de muitas opções governamentais e orientações doutrinárias.

Seja como for, aceitando-se como razoável (ainda que discutível) a tese de que o século XXI assistirá à transição do Estado-nação a uma "democracia cosmopolita e transnacional", será preciso estabelecer quais sujeitos se encarregarão dessa operação e abrir a discussão sobre o tema político do "partido transnacional de cidadãos globais" (Beck, 2001). Hoje, há uma nova dialética do global e do local que não se acomoda com facilidade na política nacional e só pode se resolver adequadamente num contexto normativo transnacional. Mas não se mostra nada simples o estabelecimento de uma teoria do partido político cosmopolita, que opere para além dos limites territoriais do Estado-nação e se cole aos movimentos nacionais e globais, aos fóruns mundiais, como representante de cidadãos globais, seguindo de perto as estratégias das grandes corporações transnacionais (Idem). À figura do "Estado-rede" imaginada por Castells (1999) deverá corresponder a figura de um "partido-rede", disposto a abrir mão de certas agendas tradicionais e de certos cálculos políticos e a empreender uma inédita construção institucional, doutrinária e cultural.

De algum modo, portanto, o avanço da globalização - que conheceu uma fase abertamente dedicada a desregulamentar e a desconstruir o Estado - trará consigo uma nova valorização do institucional, do político e do estatal. Um novo parâmetro de regulação transnacional não virá do esforço de movimentos sociais referenciados por uma idéia "social" de sociedade civil, espontaneamente estruturada e eticamente motivada. Uma eventual "sociedade civil mundial" não poderá se objetivar sem Estados fortes e sem partidos capacitados para organizar demandas particulares (individuais, grupais, locais, nacionais) em termos gerais. Por mais que se deva recusar a idéia de um único partido de vanguarda, detentor de toda a verdade, não há como adotar um relativismo absoluto, que daria razão às correntes pós-modernas, "para as quais tudo o que conta é a história imediata dos indivíduos" e o alcance de objetivos particulares, como se a "expressividade das formas de luta" pudesse substituir o conteúdo delas (Houtart, 2001, pp. 95-96). Um avanço para além dos Estados-nação não excluirá as realidades nacionais como centros de vida política e democrática. Em outros termos, conexões virtuais via Internet não dispensarão articulações ético-políticas no plano concreto da história (Moraes, 2001). Qualquer postulação utópica, de resto, deve poder precisar seus objetivos a médio e a curto prazo, e esses objetivos situam-se inevitavelmente nos campos concretos do agir coletivo.

A demarcação de um território de lutas que ignore os Estados nacionais realmente existentes, por exemplo, pode dar margem a um "internacionalismo abstrato carente de bases materiais", com o que se desfaz a possibilidade mesma de uma estratégia anti-sistêmica efetiva (Wood, 2001, p. 112). A globalização não está tornando irrelevante o Estado-nação. Por detrás de cada operação econômi- 
ca transnacional há bases nacionais que dependem de Estados locais para se viabilizarem. O Estado-nação tradicional está certamente mudando sua forma e tendendo a dar lugar a "Estados mais estreitamente locais e a autoridades políticas regionais mais amplas". Qualquer que seja sua forma, porém, ele "continuará sendo crucial e é provável que por um longo tempo ainda o velho Estado-nação continue desempenhando seu papel dominante" (Idem, p. 117).

Se assim é, o Estado ainda pode ser pensado como uma "eticidade superior", uma força educativa e unificadora contra a fragmentação e a atomização social derivadas da objetivação do capitalismo. A política ainda deve se dirigir, portanto, para "utilizar o poder do Estado para controlar os movimentos do capital e dispô-los sob o alcance de uma accountability democrática e em concordância com uma lógica social diferente da lógica da competição e da rentabilidade capitalista" (Idem, p. 119).

Como então sair desse verdadeiro impasse teórico e político? Uma aposta razoável seria empreender esforços para que a idéia de sociedade civil político-estatal (gramsciana) ganhe maior consistência teórica, se mantenha como parâmetro e, tanto quanto possível, se superponha à sociedade civil social, isolando ou neutralizando a sociedade civil liberista. A partir de uma referência como essa, pode-se imaginar o surgimento de uma força que unifique e organize o atual movimento antiglobalização e a sociedade civil a ele correspondente.

Não se trata de uma operação simples, até mesmo porque a lógica das coisas conspira contra ela. Mas, não estando morto o Estado, também não estão definitivamente enterrados os partidos e os movimentos políticos coesos, estruturados como organizações permanentes. Estamos paralisados entre a visão que absolutiza o Estado em detrimento do mercado, do indivíduo e da espontaneidade social, e a visão que imagina a sociedade como mera extensão do mercado e da livre concorrência dos interesses? Será mesmo que a história, daqui para frente, transcorrerá sob a pressão dos processos "cegos" e "incontroláveis" da globalização ou, em outra escala, sob o influxo de mo- vimentos horizontais, tendencialmente anárquicos e dispersivos, desprovidos de centros organizacionais? Poderemos seguir em frente apenas com base em ações éticas e voluntariosas, em batalhas no ciberespaço, numa movimentação frenética, generosa e incansável para encurralar e desmascarar o sistema? Será assim que construiremos a almejada sociedade civil mundial, a partir da qual poderiam ser enquadradas as múltiplas e diversificadas sociedades civis realmente existentes? Não parece razoável.

Se a resposta a essas questões não se mostra simples e gera dúvidas e divergências, creio que estamos obrigados, mais uma vez, a pensar em termos dialéticos e a articular politicamente o que está desagregado e o que se mostra concebido para funcionar em rede, sem vértices ou comandos. Se pensarmos dialeticamente, não teremos como virar as costas para o Estado, ficar longe do parlamento ou fugir da política. Não teremos como glorificar unilateralmente o mercado ou a "sociedade civil", nem como justapor a luta social à luta institucional.

O século XX nos fez enveredar por um "futuro desconhecido e problemático, mas não necessariamente apocalíptico" (Hobsbawm, 1995, p. 16). Espessas nuvens de fumaça, medo e sofrimento bloqueiam o entusiasmo, mas as possibilidades de avanço se materializam a olhos vistos.

O que virá pela frente? Tanto quanto em qualquer outra época, a história continuará a se processar como um movimento aberto, errático, repleto de alternativas. Mas a história não é apenas um jogo de circunstâncias, decisões governamentais, crises estruturais, acasos e necessidades. Nela continuarão a operar o engenho, a generosidade e o empenho democrático dos povos da terra, com suas organizações, seus líderes, suas culturas. Se o mundo se tornou mais mundo e os problemas que nos afetam são problemas globais, não há saída sem diálogo, sem perspectiva política e esforços de unificação, sem soluções globais. Se os povos da terra souberem se aproximar e dar vida a ações democratizadoras combinadas, a pressões inteligentes, a alianças sustentáveis, capazes de impor suas decisões sobre todos, conseguiremos desenhar um pacto social de novo tipo - um pacto para dignifi- 
car a comunidade humana, sem distinções de qualquer espécie e com a devida promoção dos mais frágeis - e fazer com que ele prevaleça sobre a globalização econômica.

\section{NOTA}

1 Para uma reconstrução desse tipo, remeto a Coutinho, 1999; Bobbio, 1999; Buci-Glucksmann, 1980; Gruppi, 1978; Ferreira, 1986; Nogueira, 1998a; Semeraro, 1999; Aggio, 1998; Simionatto, 1995; e Soares, 2000.

2 Foge completamente dos objetivos do presente texto a reconstituição histórica do conceito. A esse respeito, ver Bobbio, 1999; Cohen e Arato, 2000; Costa, 2002; Liguori, 1999 e 2001; Whitehead, 1999; e Bresser-Pereira, 1999.

3 É semelhante a posição de Cohen e Arato, para quem "o conceito de sociedade civil, em vários usos e definições, tornou-se moda graças às lutas contra as ditaduras comunistas e militares em muitas partes do mundo; apesar disto, seu status é ambíguo nas democracias liberais" (2000, p. 7). Seguindo caminho analítico diverso, já que considera que considerar a sociedade civil uma terceira esfera ao lado do mercado e do Estado mais confunde do que esclarece a análise das sociedades contemporâneas, Fábio Wanderley Reis observa que, "do ponto de vista das discussões teóricas deflagradas no quadro do 'pós-socialismo', a grande novidade é a retomada e o intenso reexame do conceito de sociedade civil" (2000, cap. 8).

4 A discussão a respeito do "Terceiro Setor" polariza-se freqüentemente entre a aceitação entusiasmada e a recusa categórica, ambas revestidas de idêntico ardor doutrinário. Uma coisa, porém, é pensar o "Terceiro Setor" como criação mais ou menos "espontânea" do social - um conjunto de iniciativas efetivamente dedicadas a prestar solidariedade e minorar os efeitos da exclusão social em áreas de que o Estado se ausenta ou comparece de maneira precária -, outra coisa é ver o "Terceiro Setor" como receptáculo da transferência de responsabilidades estatais, um instrumento direcionado para substituir ou refrear o Estado. Ao passo que a primeira visão não exclui necessariamente o reconhecimento da relevância estratégica da ação estatal e pode até mesmo funcionar como fator de reconstrução do pacto social, a segunda visão exige a subsunção do Estado a um mundo de interesses particulares auto-suficientes e orientados pelo mercado. Seja como for, não há qualquer motivo lógico ou político para que o combate à questão social seja travado exclusivamente a partir da ação estatal (governamental), ou seja, sem o concurso de iniciativas sociais relativamente independentes e "espontâneas", desde que devidamente regulamentadas. O mais importante, aqui, não é tanto a postulação de uma necessária presença "física" do aparato estatal, mas a defesa de uma perspectiva de Estado, quer dizer, a aceitação de que o social não se viabiliza sem uma idéia de Estado, sem uma "eticidade superior" que produza parâmetros de sentido para todos os grupos e indivíduos.

5 Para Habermas, em vez de visar a uma "política múltipla organizada no todo ao modo de um Estado mundial", o projeto de uma "democracia cosmopolita" deveria buscar se concretizar "em uma base de legitimação menos ambiciosa, a saber, nas formas de organizações não-governamentais do sistema de negociação internacional que já existe em outros âmbitos políticos". Essa orientação ofereceria a "imagem dinâmica das interferências e das interações entre os processos políticos se desenvolvendo de modo peculiar nos âmbitos nacional, internacional e global". Poder-se-ia ter, assim, uma política mundial, mas não um governo mundial. (Habermas, 2001, p. 138-139).

6 Se a grande lição a ser extraída do colapso do socialismo é a do penoso erro envolvido na pretensão de construir uma cidadania democrática socialista prescindindo inteiramente do mercado e do princípio do mercado, a experiência dos países capitalistas avançados e de tradição liberal-democrática deixa claro que a construção de uma cidadania democrática no âmbito do capitalismo não pode, por seu turno, prescindir do Estado" (Fábio W. Reis, 2000, p. 256).

\section{BIBLIOGRAFIA}

AGGIO, Alberto (org.). (1998), Gramsci: a vitalidade de um pensamento. São Paulo, Editora Unesp.

ARATO, Andrew. (1995), "Ascensão, declínio e reconstrução do conceito de sociedade civil: orientações para novas pesquisas". Revista Brasileira de Ciências Sociais, 27, fev.

AVRITZER, Leonardo (org.). (1994), Sociedade civil e democratização. Belo Horizonte, Del Rey.

BECK, Ulrich. (2001), "Democracia global: la política más allá del Estado-nación”. Metapolitica, 5 (18): 66-71, México, abr.-jun. 
BEHRING, Elaine Rossetti. (2003), "Contra-reforma do Estado, seguridade social e o lugar da filantropia”. Serviço Social \& Sociedade, 73: 101-119, São Paulo, mar.

BOBBIO, Norberto. (1999), Ensaios sobre Gramsci e o conceito de sociedade civil. Tradução de Marco Aurélio Nogueira e Carlos Nelson Coutinho. São Paulo, Paz e Terra.

BORÓN, Atílio. (1996), "A sociedade civil depois do dilúvio neoliberal", in E. Sader \& P. Gentili (orgs.), Pós-neoliberalismo: as politicas sociais e o Estado democrático, 3 ed., Rio de Janeiro, Paz e Terra.

BRESSER-PEREIRA, Luiz Carlos. (1999), "Sociedade civil: sua democratização para a reforma do Estado", in L. C. Bresser-Pereira, J. Wilheim e L. Sola (orgs.), Sociedade e Estado em transformação, São Paulo, Editora Unesp/ENAP.

BRESSER-PEREIRA, Luiz Carlos \& CUNILL-GRAU, Nuria. (1999), "Entre o Estado e o mercado: o público não-estatal", in L. C. Bresser-Pereira e N. Cunill-Grau (orgs.), Opúblico não-estatal na reforma do Estado, Rio de Janeiro, Editora Fundação Getúlio Vargas/CLAD.

BUCI-GLUCKSMANN, Christine. (1980), Gramsci e o Estado. Rio de Janeiro, Paz e Terra.

BUEY, Francisco Fernández. (2001), Leyendo a Gramsci. Barcelona, El Viejo Topo.

CASTELLS, Manuel. (1999), "Para o Estado-rede: globalização econômica e instituições políticas na era da informação", in L. C. BresserPereira, J. Wilheim e L. Sola (orgs.), Sociedade e Estado em transformação, São Paulo, Editora Unesp/ENAP.

COELHO, Simone de Castro Tavares. (2000), Terceiro Setor: um estudo comparado entre Brasil e Estados Unidos. São Paulo, Editora Senac.

COHEN, Jean L. (1999), "La scomessa egemonica: l'attuale dibattito americano sulla societá civile e i suoi dilemmi”, in G. Vacca (org.), Gramsci e il Novecento, Roma, Carocci editore, vol. 1.
COHEN, Jean L. \& ARATO, Andrew. (2000), Sociedad civil y teoría politica. México, Fondo de Cultura Económica.

COSTA, Sérgio. (2002), As Cores de Ercília: esfera pública, democracia, configurações pós-nacionais. Belo Horizonte, Editora da UFMG.

COUTINHO, Carlos Nelson. (1999), Gramsci: um estudo sobre seu pensamento político. Rio de Janeiro, Civilização Brasileira (edição revista e ampliada).

(2000), "La societá civile in Gramsci e il Brasile di oggi". Critica Marxista, 3-4: $67-$ 81, Roma, jun.-ago.

DAHRENDORF, Ralf. (1997), Após 1989. Moral, revolução e sociedade civil. Rio de Janeiro, Paz e Terra.

EVERS, Tilman. (1983), "De costas para o Estado, longe do Parlamento". Novos Estudos Cebrap, 2 (1): 25-39, abr.

FERNANDES, Rubem César. (1994), Privado porém público: o terceiro setor na América Latina. Rio de Janeiro, Relume-Dumará.

FERREIRA, Oliveiros S. (1986), Os 45 cavaleiros búngaros: uma leitura dos Cadernos de Gramsci. São Paulo, Hucitec.

FROSINI, Fabio. (2003), Gramsci e la filosofia: saggio sui Quaderni del carcere. Roma, Carocci Editore.

GÓMEZ, José Maria. (2000), Política e democracia em tempos de globalização. Petrópolis, Vozes.

GRAMSCI, Antonio. (1999), Cadernos do cárcere (vol. 1: Introdução ao estudo da filosofia. A filosofia de Benedetto Croce. Edição e tradução de Carlos Nelson Coutinho e Luiz Sérgio Henriques), Rio de Janeiro, Civilização Brasileira.

(2000), Cadernos do cárcere (vol. 3: Maquiavel. Notas sobre o Estado e a politica. Edição e tradução de Carlos Nelson Coutinho e Luiz Sérgio Henriques), Rio de Janeiro, Civilização Brasileira.

(1987), "Alguns temas da questão meridional”, in A. Gramsci, A questão meridional, 
tradução de Carlos Nelson Coutinho e Marco Aurélio Nogueira, Rio de Janeiro, Paz e Terra.

GRUPPI, Luciano. (1978), O conceito de begemonia em Gramsci. Rio de Janeiro, Graal.

HABERMAS, Jurgen. (1997a), Teoria dell'agire comunicativo. Bologna, Il Mulino.

(1997b), Direito e democracia: entre facticidade e validade. Rio de Janeiro, Tempo Brasileiro, 2 vols.

(2001), A constelação pós-nacional. São Paulo, Littera Mundi.

HOBSBAWM, Eric. (1995), Era dos extremos: o breve século XX, 1914-1991. São Paulo, Companhia das Letras.

HOUTART, François. (2001), "A mundialização das resistências e das lutas contra o neoliberalismo", in J. Seoane e E. Taddei (orgs.), Resistências mundiais: de Seattle a Porto Alegre, Petrópolis, Vozes/CLACSO.

IOSCHPE, Evelyn Berg (org.). (1997), $3^{\circ}$ setor: desenvolvimento social sustentado. São Paulo, GIFE/Paz e Terra.

KEANE, John. (2001), Civil Society: old images, new visions. Stanford, Stanford University Press.

LAVALLE, Adrián Gurza. (1999), "Crítica ao modelo da nova sociedade civil". Lua Nova, 47: 121-135, São Paulo.

LIGUORI, Guido. (1999), "Stato e società civile da Marx a Gramsci", in G. Petronio e M. P. Musitelli (orgs.), Marx e Gramsci: memoria e attualità, Roma, Manifestolibri.

(2001), "La società civile da Gramsci a Berlusconi”. Critica Marxista, 2-3: 43-51, Roma, nov.-dez.

MONTAÑO, Carlos. (2002), Terceiro setor e questão social: crítica ao padrão emergente de intervenção social. São Paulo, Cortez.

MORAES, Dênis de. (2001), O concreto e o virtual: mídia, cultura e tecnologia. Rio de Janeiro, DP\&A.

NOGUEIRA, Marco Aurélio. (1998a), "Gramsci e os desafios de uma política democrática de esquerda”, in A. Aggio (org.), Gramsci: a vitalidade de um pensamento, São Paulo, Editora Unesp.

. (1998b), As possibilidades da política: idéias para a reforma democrática do Estado. São Paulo, Paz e Terra.

(2000/2001), "Gramsci desembalsamado: em torno dos abusos do conceito de sociedade civil”. Educação em Foco, 5 (2): 115 130, Juiz de Fora, set.-fev.

(2001), Em defesa da política. São Paulo, Editora Senac.

REIS, Fábio Wanderley. (2000), Mercado e utopia. São Paulo, Edusp.

SEMERARO, Giovanni. (1999), Gramsci e a sociedade civil: cultura e educação para a democracia. Petrópolis, Vozes.

SEOANE, José \& TADDEI, Emílio (orgs.). (2001), Resistências mundiais: de Seattle a Porto Alegre. Petrópolis, Vozes/CLACSO.

SIMIONATTO, Ivete. (1995), Gramsci: sua teoria, incidência no Brasil, influência no serviço social. São Paulo, Cortez.

SOARES, Rosemary Dore. (2000). Gramsci, o Estado e a escola. Ijuí, Editora Unijuí.

TORRES, Júlio César. (2003), "Sociedade civil como recurso gerencial? Indagações acerca da política de Assistência Social no Brasil. Serviço Social E Sociedade, 73: 142-156, São Paulo, mar.

TORTORELLA, Aldo. (1998), "O fundamento ético da política em Gramsci”. Lua Nova, 43: 5768, São Paulo.

VIEIRA, Lizt. (2001), Os argonautas da cidadania: a sociedade civil na globalização. Rio de Janeiro, Record.

WALZER, Michael (ed.). (1998), Toward a global civil society. Oxford, Berghahn Books.

WHITEHEAD, Laurence. (1999), "Jogando boliche no Bronx: os interstícios incivis entre a sociedade civil e a sociedade política”. Revista 
Brasileira de Ciências Sociais, 14 (41): 15-30,

São Paulo, out.

WOOD, Ellen Meiksins. (2001), "Trabalho, classe e Estado no capitalismo global", in J. Seoane e E. Taddei (orgs.), Resistências mundiais: de Seattle a Porto Alegre, Petrópolis, Vozes/CLACSO. 